\title{
The effect of medicinal herb on fat deposition, meat composition, amino acid and fatty acid composition of broiler meats
}

\author{
U. Santoso*, Y. Fenita, Kususiyah, O. Widiantoro and S. Kadarsih \\ Department of Animal Science, Agriculture Faculty, Bengkulu University \\ Jalan Raya WR Suprtaman, Kandang Limun, Bengkulu - Indonesia \\ CorrespondingE-mail: santoso@unib.ac.id
}

Received August 31, 2017; Accepted January 03, 2018

\begin{abstract}
ABSTRAK
Penelitian ini bertujuan untuk mengevaluasi pengaruh pemberian tumbuhan obat terhadap deposisi lemak, komposisi kimia, asam amino dan asam lemak daging broiler betina. Seratus enam puluh delapan broiler betina umur 15 hari didistribusikan ke dalam 7 kelompok sebagai berikut: 1) broiler diberi pakan tanpa tumbuhan obat sebagai kontrol (P0) 2) broiler diberi pakan yang mengandung katuk 5\% (P1); 3) broiler diberi pakan yang mengandung daun salam $5 \%(\mathrm{P} 2) ; 4)$ broiler diberi pakan yang mengandung $5 \%$ daun kemangi (P3) 5) broiler diberi pakan yang mengandung 5\% daun pepaya (P4); 6) broiler diberi pakan yang mengandung daun kelor 5\% (P5) dan; 7) broiler diberi pakan yang mengandung buah mengkudu 5\%. Hasil penelitian menunjukkan bahwa pemberian tumbuhan obat meningkatkan protein $(\mathrm{P}<0,01)$, besi $(\mathrm{P}<0,05)$, kalium, kalsium, fosfor, linolenic acid $(\mathrm{P}<0,01)$, methionine dan asam lemak tak jenuh omega $3(\mathrm{P}<0,05)$, tetapi menurunkan kadar lemak, oleic acid, lignoneric acid $(\mathrm{P}<0,01)$ dan omega-9 $(\mathrm{P}<0,05)$. Dapat disimpulkan bahwa daun katuk merupakan tumbuhan obat yang paling efektif untuk menghasilkan daging broiler yang rendah lemak tetapi tinggi protein, linolenic acid dan mineral.

Kata Kunci: tumbuhan obat, deposisi lemak, komposisi daging, asam amino, asam lemak, broiler
\end{abstract}

\begin{abstract}
The present study was conducted to evaluate the effect of medicinal herb inclusion on fat deposition, chemical composition, amino acid and fatty acid of broiler meats. One hundred-sixty eight female broiler chickens aged 15 days were distributed into 7 groups as follows: 1) broilers were fed a diet with no medicinal herb as the control (P0) 2) broilers were fed a diet with 5\% Sauropus androgynus leaf powder (P1);3) broilers were fed a diet with 5\% bay leaf powder (P2);4) broilers were fed a diet with 5\% basil leaf powder (P3) 5) broilers were fed a diet with 5\% papaya leaf powder (P4); 6) broilers were fed a diet with 5\% Moringa leaf powder (P5) and; 7) broilers were fed a diet with 5\% noni fruit powder. Experimental results showed that the inclusion of medicinal herbs significantly increased protein $(\mathrm{P}<0.01)$, iron $(\mathrm{P}<0.05)$, kalium, calcium, phosphorus, linolenic acid $(\mathrm{P}<0.01)$, methionine, omega 3 unsaturated fatty acid $(\mathrm{P}<0.05)$, but significantly reduced fat $(\mathrm{P}<0.01)$, glutamic acid, alanine, lignoceric acid, oleci acid $(\mathrm{P}<0.01)$ and omega 9 unsaturated fatty acid $(\mathrm{P}<0.05)$. It was concluded that Sauropus androgynus leaf was the most effective to produce low fat-high protein and mineral meats.
\end{abstract}

Keywords :medicinal herbs, fat deposition, meat composition, amino acid, fatty acid, broilers

\section{INTRODUCTION}

Although commercial feed additive containing antibiotics can increase productivity, antibiotic residues in meats might have negative effects on human health when meats were consummed (Barton and Hart, 2001; Imik et al., 2006; Khaksefidi and Rahimi, 2005). In addition, 
commercial feed additives do not contain compounds in order to produce enriched meats (meats with low-fat but rich in protein and mineral). Thus, it needs alternative feed additives, which are safer, drug-free residue and to meet consumer demand.

To overcome these problems, some antioxidant medicinal herbs have been suggested as replacements for antibiotics (Liu et al., 2006; Santoso, 2001; Santoso et al., 2000). These medicinal herbs have low side effect and maintain product quality and livestock performance (Simitzis et al., 2008). Antioxidant compounds found in medicinal herbs include $\alpha$-tocopherol (vitamin E), $\beta$-carotene, ascorbic acid, flavonoids, carotenoids, anthocyanins, phenols, zinc and selenium (Moyo et al., 2012; Atowadi et al., 2010). Basil leaves, Sauropus androgynus leaves, bay leaves, noni fruit, papaya leaves, and Moringa leaves have potential as alternative feed additives.

Santoso et al. (2005) showed that the supplementation of aqueous extract of Sauropus androgynus leaves reduced egg cholesterol contents at $40 \%$. In another study (Santoso et al., 2001), the aqueous extract reduced abdominal fat deposition at $20 \%$ and decreased carcass fat content at 10\%. Santoso and Sartini (2001) reported that the inclusion of Sauropus androgynus leaves powder at $3 \%$ reduced abdominal fat as much as $30 \%$.

Santoso and Fenita (2015) reported that papaya leaves powder increased protein levels in eggs. Fenita et al. (2011) showed that $75 \mathrm{~mL}$ noni juice/1 liter of drinking water reduced fat content by $30 \%$ and increased protein content by $20 \%$. Hamiyanti et al. (2013) reported that adding $0.75 \%$ basil leaves powder to the diet increased protein levels, but lowered fat and cholesterol levels of broiler meat. Restiayanti et al. (2014) reported that the administration of Moringa leaf extract at $50 \mathrm{~g} /$ liter drinking water decreased abdominal fat deposition and blood cholesterol in broiler chcikens. The inclusion of bay leaves powder reduced cholesterol levels of broiler carcasses (Suharti et al., 2008). Few studies have reported pertaining effect of medicinal herbs on amino acid and fatty acid compositions of broiler meats.

The present study was conducted to compare the effectiveness of selected medicinal herbs in modifying fat deposition, the contents of protein, fat, moisture, cholesterol, iron, kalium, calsium, phosphorus, amino acid, and fatty acid of broiler meats.

\section{MATERIALS AND METHODS}

\section{Medicinal Herb Powder}

Basil leaves, Sauropus androgynus leaves, bay leaves, noni fruit, papaya leaves, and Moringa leaves obtained from the field were airdried for 5 days, milled ( $1 \mathrm{~mm}$ size) and stored in plastic bags before formulating into experimental diets.

\section{Animal and Exprimental Diets}

Three hundred broiler chickens aged one day were placed in the brooder. Broilers were given drinking water containing sugar to eliminate the stress. Brooder temperature was set in accordance with the standards of maintenance procedures. At the age of 4 and 21 days, broiler chickens were vaccinated Newcastle Disease. They were diet commercial diets from 1-13 days of age.

One hundred sixty-eight female broiler chickens aged 15 days were distributed into 7 groups. Each treatment group consisted of 4 replicates, and each replicate consisted of 6 female broiler chickens. The 7 treatments were as follows: 1) female broilers were fed a diet with no medicinal herb as the control (P0) 2) female broilers were fed a diet with 5\% Sauropus androgynus leaf powder (P1);3) female broilers were fed a diet with $5 \%$ bay leaf powder (P2); 4) female broilers were fed a diet with $5 \%$ basil leaf powder (P3) 5) female broilers were fed a diet with $5 \%$ papaya leaf powder (P4); 6) female broilers were fed a diet with 5\% Moringa leaf powder (P5) and; 7) female broilers were fed a diet with 5\% noni fruit powder. Experimental diets contained $19 \%$ crude protein and $3.200 \mathrm{kcal}$ $\mathrm{ME} / \mathrm{kg}$. The feedstuffs composition used in the present study was published elsewhere (Santoso et al., 2017b).

\section{Sampling and Laboratory Analysis}

At the end of the study (aged 35 days), four female broiler chickens from each treatment group were selected and slaughtered. Fat from abdomen, gizzard, sartorial, neck and heart were removed and weighted. Fatty liver score was determined by comparing the liver color with color standard from 1-5 values. Greater values showed greater fat deposition in the liver.

The leg meats were then collected, grounded and stored at $-30^{\circ} \mathrm{C}$ before analysis. Fat, protein, moisture, iron, kalium, calcium and phosphorus 
were determined by the method of AOAC (2012), whereas cholesterol was determined by the method as described by Dinh et al. $(2008,2011)$. Amino acid composition was measured by the method as described by Henderson and Brooks (2010), and fatty acid composition was determined by the method as described by Almeida et al. (2006).

\section{Statistical Analysis}

The experimental results were subjected to a one-way analysis of variance. Significant differences among the treatment groups were determined by Duncan's Multiple Range Test.

\section{RESULTS AND DISCUSSION}

\section{Fat Deposition}

Table 1 shows the effect of medicinal herb on fat deposition and fatty liver score in female broiler chickens. Experimental results showed that the inclusion of medicinal herbs had no effect on abdominal fat, sartorial fat, neck fat, gizzard fat, heart fat and fatty liver score.

The results showed that selected medicinal herbs could not reduce fat deposition in female broiler chickens. Santoso et al. (2017b) reported that Sauropus androgynus leaves, papaya leaves, bay leaves, basil leaves, Moringa leaves and noni fruit contained flavonoids, tannins and phenols. It has been established that these compounds had antilipid properties (Aiura and de Carvalho, 2007; Zang et al., 2006; Zarrouki et al., 2010). Thus, the contents of these compounds in those medicinal herbs were inadequate to reduce fat depostion.

This study disagrees with the observation of Santoso and Sartini (2001) that the inclusion of Sauropus androgynus leaf powder at 3\% reduced abdominal fat deposition, and Restiayanti et al. (2014) that the supplementation of Moringa leaf extract through drinking water reduced abdominal fat deposition. However, the present study agrees with the observation of Tazi (2014) in which the inclusion of Moringa at 3-7\% had no effect on abdominal fat deposition in broiler chickens. Gurbuz and Ismael (2016) reported that the inclusion of basil leaves at 3\% did not reduce abdominal fat deposition in broiler chickens. Fenita et al. (2011) stated that the supplementation of noni juice did not reduce abdominal fat in broiler chickens. Abdalla et al. (2013) reported that the inclusion of papaya leaves powder at $10 \%$ did not reduce abdominal fat pad. Santoso (2015) stated that the supplementation of papaya leaf extract had no effect on the fatty liver score.

\section{Meat Composition}

Table 2 shows the effect of medicinal herb on chemical composition of female broiler meats. Experimental results showed that the inclusion of medicinal herbs significantly affected fat $(\mathrm{P}<0.05)$, protein $(\mathrm{P}<0.01)$, iron $(\mathrm{P}<0.05)$, kalium, calcium and phosphorus $(\mathrm{P}<0.01)$ but had no effect on cholesterol and moisture. DMRT test showed that fat content of P1 and P4 were lower than the other treatment groups $(\mathrm{P}<0.01)$. The protein content of $\mathrm{P} 3$ was lower than $\mathrm{P} 0, \mathrm{P} 1, \mathrm{P} 2$, $\mathrm{P} 4$ and P5. The iron content of P1 and P5 were higher than P0 and P2. Kalium content of P0 was lower than the other treatment groups, whereas that of P6 was the highest. The calcium content of P0 was lower than that of P1, P2, P4 and P6. The phosphorus content of $\mathrm{P} 0$ was lower than that of P1, P4, P5 and P6. The phosphorus content of the $\mathrm{P} 6$ and $\mathrm{P} 4$ was higher than that of $\mathrm{P} 1$ and $\mathrm{P} 5$.

The compounds that play a role in lowering fat contents in P1 and P4 might be flavonoids, tannins and phenols (Aiura and de Carvalho, 2007; Zang et al., 2006; Zarrouki et al., 2010). Santoso et al. (2017b) reported that Moringa leaves, noni fruit, papaya leaves, Sauropus androgynus leaves, basil leaves and bay leaves contained iron at level of $2.00 \mathrm{ppm}, 7.80 \mathrm{ppm}$, $5.61 \mathrm{ppm}, 4.02 \mathrm{ppm}, 6.43 \mathrm{ppm}$ and $1.59 \mathrm{ppm}$, respectively. Thus, Moringa leaves and Sauropus androgynus had lower iron content than noni fruit, papaya leaves and basil leaves. It is assumed that the iron availability of Moringa dan Sauropus androgynus leaves may be higher resulting in higher iron content of meats. These selected medicinal herbs had high kalium content. The kalium content of Moringa leaves, Sauropus androgynus leaves, papaya leaves, basil leaves, bay leaves and noni fruit were $1324 \mathrm{mg}$ kalium, $2610 \mathrm{mg}$ kalium, 6762.50-8754.50 mg kalium, $550 \mathrm{mg}$ kalium and 875-2271.2 mg kalium/100 g dry weight, respectively (Alaa et al., 2016; Basar and Westendorf, 2012; Dzida, 2010; Gopalakkrishnan et al., 2016; Hoe and Siong, 1999; Sharma et al., 2013). Thus, higher kalium content of the selected medicinal herbs might contribute to higher meat kalium content. The contents of calcium and phosphorus in the experimental diets were relatively similar among the treatments (Santoso et al., 2017b). It is postulated that the availability of calcium and phosphorus in the certain medicinal herbs might 
Table 1. The Effect of Medicinal Herb on Fat Deposition and Fatty Liver Score in Female Broiler Chcikens

\begin{tabular}{|c|c|c|c|c|c|c|c|c|}
\hline Variables & $\mathrm{P} 0$ & P1 & $\mathrm{P} 2$ & P3 & $\mathrm{P} 4$ & P5 & P6 & $\begin{array}{c}\text { P- } \\
\text { values }\end{array}$ \\
\hline Abdomen, $\%$ & $1.30 \pm 0.53$ & $1.22 \pm 0.24$ & $1.30 \pm 0.60$ & $1.29 \pm 0.08$ & $1.17 \pm 0.12$ & $1.08 \pm 0.29$ & $1.60 \pm 0.29^{\mathrm{ns}}$ & 0.378 \\
\hline Sartorial, \% & $0.55 \pm 0.21$ & $0.54 \pm 0.23$ & $0.59 \pm 0.17$ & $0.79 \pm 0.09$ & $0.52 \pm 0.11$ & $0.54 \pm 0.18$ & $0.61 \pm 0.25^{\mathrm{ns}}$ & 0.558 \\
\hline Neck, \% & $0.05 \pm 0.01$ & $0.04 \pm 0.02$ & $0.05 \pm 0.02$ & $0.04 \pm 0.01$ & $0.04 \pm 0.01$ & $0.05 \pm 0.02$ & $0.04 \pm 0.01^{\mathrm{ns}}$ & 0.836 \\
\hline Gizzard, \% & $0.68 \pm 0.20$ & $0.49 \pm 0.15$ & $0.60 \pm 0.17$ & $0.62 \pm 0.09$ & $0.54 \pm 0.06$ & $0.47 \pm 0.05$ & $0.45 \pm 0.14$ & 0.199 \\
\hline Heart, \% & $0.06 \pm 0.02$ & $0.05 \pm 0.03$ & $0.07 \pm 0.01$ & $0.06 \pm 0.02$ & $0.07 \pm 0.01$ & $0.06 \pm 0.02$ & $0.05 \pm 0.02^{\mathrm{ns}}$ & 0.885 \\
\hline FLS & $1.2 \pm 0.24$ & $1.0 \pm 0$ & $1.3 \pm 0.29$ & $1.3 \pm 0.47$ & $1.4 \pm 0.48$ & $1.0 \pm 0$ & $1.3 \pm 0.29^{\mathrm{ns}}$ & 0.523 \\
\hline
\end{tabular}

$\mathrm{P} 0=$ the control; $\mathrm{P} 1=$ Sauropus androgynus leaf; P2= Bay leaf; P3= Basil leaf; P4= Papaya leaf; P5= Moringa leaf; P6= Noni fruit. FLS= fatty liver score

Table 2. The Effect of Medicinal Herb on Chemical Composition of Female Broiler Meats

\begin{tabular}{|c|c|c|c|c|c|c|c|c|}
\hline Variables & $\mathrm{P} 0$ & $\mathrm{P} 1$ & $\mathrm{P} 2$ & P3 & P4 & P5 & P6 & $\begin{array}{c}\mathrm{P}- \\
\text { values }\end{array}$ \\
\hline $\begin{array}{l}\text { Fat, } \\
\%\end{array}$ & $7.72 \pm 1.04^{b}$ & $5.66 \pm 0.38^{\mathrm{a}}$ & $6.95 \pm 0.40^{\mathrm{b}}$ & $6.99 \pm 1.60^{b}$ & $5.96 \pm 0.88^{\mathrm{a}}$ & $6.83 \pm 0.10^{\mathrm{b}}$ & $7.55 \pm 0.37^{b^{*}}$ & 0.019 \\
\hline $\begin{array}{l}\text { Protein, } \\
\%\end{array}$ & $16.27 \pm 0.38^{\mathrm{bc}}$ & $16.75 \pm 0.14^{\mathrm{c}}$ & $16.20 \pm 0.12^{\mathrm{b}}$ & $15.74 \pm 0.38^{\mathrm{a}}$ & $16.47 \pm 0.19^{b c}$ & $15.89 \pm 0.13^{\mathrm{ab}}$ & $16.40 \pm 0.24^{\mathrm{bc} * *}$ & 0.000 \\
\hline $\begin{array}{l}\text { Moisture, } \\
\%\end{array}$ & $69.89 \pm 0.72$ & $69.24 \pm 0.24$ & $69.69 \pm 0.44$ & $69.20 \pm 0.84$ & $68.72 \pm 0.27$ & $69.49 \pm 1.34$ & $68.18 \pm 1.12^{\mathrm{ns}}$ & 0.100 \\
\hline $\begin{array}{l}\text { Cholesterol, } \\
\mathrm{mg} / 100 \mathrm{~g}\end{array}$ & $2.17 \pm 0.10$ & $1.94 \pm 0.07$ & $1.89 \pm 0.11$ & $2.04 \pm 0.11$ & $2.07 \pm 0.25$ & $2.05 \pm 0.03$ & $1.93 \pm 0.12^{\mathrm{ns}}$ & 0.066 \\
\hline $\begin{array}{l}\text { Iron, } \\
\mathrm{mg} / 100 \mathrm{~g}\end{array}$ & $1.55 \pm 0.07^{\mathrm{ab}}$ & $1.65 \pm 0.10^{\mathrm{c}}$ & $1.59 \pm 0.03^{\mathrm{ab}}$ & $1.60 \pm 0.04^{\mathrm{abc}}$ & $1.64 \pm 0.05^{\mathrm{bc}}$ & $1.52 \pm 0.03^{\mathrm{a}}$ & $1.63 \pm 0.03^{\mathrm{bc} *}$ & 0.027 \\
\hline $\begin{array}{l}\text { Kalium, } \\
\mathrm{mg} / 100 \mathrm{~g}\end{array}$ & $1.35 \pm 0.03^{\mathrm{a}}$ & $1.41 \pm 0.03^{b}$ & $1.41 \pm 0.03^{\mathrm{b}}$ & $1.41 \pm 0.02^{\mathrm{b}}$ & $1.43 \pm 0.02^{b c}$ & $1.40 \pm 0.02^{\mathrm{b}}$ & $1.46 \pm 0.02^{\mathrm{c}^{* *}}$ & 0.000 \\
\hline $\begin{array}{l}\text { Calcium, } \\
\mathrm{mg} / 100 \mathrm{~g}\end{array}$ & $13.50 \pm 0.38^{\mathrm{ab}}$ & $14.13 \pm 0.14^{\mathrm{c}}$ & $14.15 \pm 0.10^{\mathrm{c}}$ & $13.35 \pm 0.30^{\mathrm{a}}$ & $13.98 \pm 0.20^{\mathrm{c}}$ & $13.91 \pm 0.27^{\mathrm{bc}}$ & $14.16 \pm 0.56^{\mathrm{c}^{* *}}$ & 0.004 \\
\hline $\begin{array}{l}\text { Phosphorus, } 1 \\
\mathrm{mg} / 100 \mathrm{~g}\end{array}$ & $197.3 \pm 5.74^{\mathrm{a}}$ & $209.5 \pm 6.24^{b}$ & $208.0 \pm 0.82^{\mathrm{ab}}$ & $208.5 \pm 6.40^{\mathrm{ab}}$ & $225.8 \pm 11.76^{\mathrm{c}}$ & $213.8 \pm 7.93^{b}$ & $224.3 \pm 5.74^{\mathrm{c}^{* *}}$ & 0.000 \\
\hline
\end{tabular}

$\mathrm{P} 0=$ the control; $\mathrm{P} 1=$ Sauropus androgynus leaf; $\mathrm{P} 2=$ Bay leaf; $\mathrm{P} 3=$ Basil leaf; $\mathrm{P} 4=$ Papaya leaf; $\mathrm{P} 5=$ Moringa leaf; $\mathrm{P} 6=$ Noni fruit.

be higher. The mechanism of lower meat protein content of meats in female broiler chcikens fed diet containing basil leaves is unkown.

This study agrees with the observation of Santoso and Sartini (2001) that the inclusion of Sauropus androgynus leaves powder at 3\% reduced carcass fat in broiler chickens. Santoso et al. (2015) reported that the inclusion of fermented Sauropus androgynus leaves powder at 5\% reduced meat fat in broiler chickens. However, the present study disagrees with the observation of Fenita et al. (2011) in which supplementation of noni fruit juice at $25-75 \mathrm{~mL} /$ litre drinking water reduced fat content of broiler meats; Hamiyanti et al. (2013) that basil leaf reduced fat content in broiler meat; Santoso and Fenita (2015) that the inclusion of papaya leaf powder increased fay content in quail eggs and; Ismoyowati et al. 
(2016) that the inclusion of bay leaf at $6-9 \%$ reduced meat fat of duck. It appears that the medicinal herb effect is affected by species and animal ages.

The present study showed lower protein content of meats in broiler chickens fed diet containing basil leaf as compared with the control, whereas other treatment groups statistically similar to the control. The present study disagrees with the results of Fenita et al. (2011) that noni fruit juice increased meat protein in broiler chickens; and Santoso and Fenita (2015) who reported that the inclusion of papaya leaf powder increased protein contents in quail eggs. The low protein content in broiler chicken fed diet containing basil leaf in the present study was in contrast with the observation of Hamiyanti et al. (2013) who reported that the inclusion of basil leaf powder at $0.75-1.25 \%$ increased protein content of broiler meat.

The present study showed that the inclusion of the selected medicinal herbs had no effect on the cholesterol content of broiler meats. This study disagrees with Hamiyanti et al. (2013) who reported that basil leaf reduced cholesterol; Tonga et al. (2016) who reported that the inclusion of Moringa leaf powder at $3-12 \%$ reduced cholesterol content of broiler meat; Ismoyowati et al. (2016) who reported that the inclusion of bay leaf at $9 \%$ reduced meat cholesterol in duck and Sujana et al. (2007) who reported that the noni fruit powder reduced cholesterol content of broiler meat. The present study agrees with the observation of Suharti et al. (2008) that the inclusion of bay leaf podwer at 1-3\% did not reduce cholesterol content of broiler carcass.

Santoso et al. (2017b) reported that Moringa leaf, noni fruit, papaya leaf, Sauropus leaf, basil leaf, and bay leaf contained iron at a level of 2 ppm, 7.80 ppm, $5.61 \mathrm{ppm}, 4.02 \mathrm{ppm}, 6.43 \mathrm{ppm}$, $1.59 \mathrm{ppm}$, respectively. It appears that the availability of iron of Sauropus androgynus leaf is higher than the others resulting in the highest iron content of broiler meats. This study agrees with Santoso et al. (2015) who reported that the supplementation of fermented Sauropus androgynus increased iron content of broiler meats.

Iron from Moringa leaf may be not adequate to improve the iron content of broiler meat in the present study, resulting in similar iron content of broiler meat as compared with the control. This study disagrees with the results of Suzana et al. (2017) that the Moringa leaves extract could improve iron deficiency anemia in women, and Tessera et al. (2015) who reported that 5\% Moringa leaves powder blended cookies have a potential to supply $53.6 \%$ of Fe to satisfy the RDA $(9 \mathrm{mg} /$ day) required by lactating mothers. In general, it might have a possibility to contribute better $\mathrm{Fe}$ content for lactating mothers to combat Iron deficiency problems. The difference of results may be caused by difference of species used in the study.

All the selected medicinal herbs increased kalium content of broiler meats. The present study disagrees with the observation of Santoso et al. (2010) that the supplementation of Sauropus androgynus did not increase the kalium content of broiler meat. No study was found on the effect of the other medicinal herbs on the kalium content of broiler meats. A higher kalium in broiler meat in P1, P2, P3, P4, P5 and P6 may be benefit for human health. Avani (2013) stated that within the body, kalium is the principal cation in intracellular fluid and participates in acid-base balance, regulation of osmotic pressure, conduction of nerve impulses, muscle contraction, cell membrane function and more. A high dietary intake of kalium has been shown to protect people from a number of conditions that affect the cardiovascular system, kidneys, and bones, and decrease blood pressure.

There is no study pertaining effect of the selected medicinal herbs on calcium and phosphorus contents of broiler meats. A higher phosphorus in broiler meat in P1, P4, P5 and P6 and calcium in P1, P2, P4 and P6 may be benefit for human helath. Renkema et al. (2008) stated that the control of plasma calcium $\left(\mathrm{Ca}^{2+}\right)$ and phosphate (Pi) levels is essential to the performance of many vital physiological functions. Muscle contraction, blood clotting and neuronal excitation all require $\mathrm{Ca}^{2+}$, whereas $\mathrm{Pi}$ is vital to intracellular signaling, as a component of membrane lipids and to build the backbone of DNA. Moreover, significant elements of bone are $\mathrm{Ca} 2+$ and Pi. Thus, Sauropus androgynus leaves, bay leaves, papaya leaves and noni fruit may be able to prevent osteoporotic conditions.

\section{Amino Acid Composition}

The effect of medicinal herb on amino acid composition of female broiler meats is presented in Table 3. Experimental results showed that the inclusion of medicinal herbs significantly affected glutamic acid $(\mathrm{P}<0.01)$ and alanine $(\mathrm{P}<0.01)$, and methionine $(\mathrm{P}<0.05)$ but had no effect on other 
amino acids. $\mathrm{P} 0$ had higher glutamic acid than $\mathrm{P} 1$, P2, P3, P4, P5 and P6 $(\mathrm{P}<0.01)$. P5 and P6 had lower alanine than $\mathrm{P} 0, \mathrm{P} 1, \mathrm{P} 2, \mathrm{P} 3$ and $\mathrm{P} 4$. P0 and $\mathrm{P} 2$ had lower methionine than P1, P3, P4 and P6 but statistically similar to P5.

Moringa leaves, Sauropus androgynus leaves, basil leaves and bay leaves contained glutamic acid at level of $15.14 \mathrm{~g} / 100 \mathrm{~g}$ protein (Okereke and Akaninwor, 2013), 2.221\% (Santoso et al., 2015), $0.11 \mathrm{mg} / \mathrm{g}$ extract (Bleiziffer et al., 2017), $621.2 \mathrm{mg} \%$ dry basis (Lee et al., 2005), respectively. Although selected medicinal herbs contained relatively high glutamic acid, the glutamic acid contents of meats were lower than the control group. The mechanism of lower meat glutamic acid is unknown.

Moringa leaf contained $0.99 \mathrm{~g}$ methionine/100 dry weight (Olaofe et al., 2013); noni fruit contained $3 \mathrm{mg}$ methionine/100 g pulp (Lindsay and Golden, 2012); bay leaf contained methionine $80.3 \mathrm{mg} \%$ dry weight (Lee et al., 2005), Sauropus androgynus leaf (sun-dried leaf) contained $0.281 \%$ methionine (Santoso et al., 2015). Methionine present in the selected medicinal herbs may contribute to an increase in methionine content of broiler meats. Sauropus androgynus leaf extract increased the number of Bacillus subtilis and Lactobacillus sp. in gastrointestinal tract (Santoso et al., 2001). AlFataftah et al. (2013) reported that an increase in Lactobacillus $s p$ enhanced the methionine content of broiler meats. They also reported that the microbial strains had potential for enhancing biosynthesis of methionine.

The mechanism of lower meat alanine in broiler fed diets containing either Moringa leaf or noni fruit is unknown. Moringa leaf contained $3.29 \mathrm{~g}$ alanine $/ 100 \mathrm{~g}$ dry weight (Olaofe et al., 2013), whereas noni fruit contained $15 \mathrm{mg}$ alanine/100 g noni pulp (Lindsay and Golden, 2012). Alanine can be synthesized from pyruvate and branched chain amino acids such valine, leucine and isoleucine. It appears that Moringa leaf and noni fruit may have antinutrition,whch inhibit alanine synthesis or reduce alanine availability.The present study disagrees with the observation of Santoso et al. (2015) who reported that fermented Sauropus androgynus leaf powder increased glutamic acid, aspartic acid, glysine, histidine, arginine, alanine, proline, tyrosine, valine, leucine, phenylalanine, and lysine of broiler meats but did not increase methionine. Santoso and Fenita (2016) reported that the inclusion of Sauropus androgynus leaf extract increased glutamic acid of egg but no effect on methionine and alanine. Santoso et al. (2017a) reported that the inclusion of Sauropus androgynus leaf extract had no effect on methionine and alanine of eggs. There is no study pertaining effect of bay leaf, basil leaf, papaya leaf, Moringa leaf and noni fruit on amino acid composition of broiler meats.

\section{Fatty Acid Composition}

The effect of medicinal herb on fatty acid composition of female broiler meats is presented in Table 4. Experimental results showed that the inclusion of medicinal herbs significantly affected oleic acid $(\mathrm{P}<0.05)$, linolenic acid $(\mathrm{P}<0.01)$, lignoceric acid $(\mathrm{P}<0.05)$, omega 3 -unsaturated fatty acid $\mathrm{P}<0.05$ ), and omega 9-unsaturated fatty acid but had no effect on other fatty acids. P2 and P3 had lower oleic acid than P0, P2 and P5. P0 had lower linolenic acid than P1, P2, P3, P4. P5, and P6. P4, P5 and P6 had lower lignoceric acid than P0, P1, P2 and P3. P2 had the highest lignoceric acid. P0 had lower omega 3 unsaturated fatty acids than the other groups. P3, P4 and P6 had lower omega 9 than P0, P1, P2 and P5.

Moringa leaves oil contained $9.32 \%$ linolenic acid, $48.88 \%$ oleic acid and $0.72 \%$ lignoseric acid (Al Juhaimi et al., 2016). Sauropus androgynus leaves contained $21.39 \%$ oleic acid and $0.14 \%$ linolenic acid (Santoso, 2014). Basil leaves contained 325.88 ppm oleic acid, $29.57 \mathrm{ppm}$ linolenic acid (Vidhani et al., 2016). Bay leaf contained $12.3 \%$ oleic acid, $17.8 \%$ linolenic acid and 6\% lignoceric acid (Lee et al., 2005). The data may indicate that higher meat linolenic acid in broiler chickens fed diet containing medicinal herbs may result from the inclusion of linolenic acid from medicinal herbs. However, it is unkownm why meat oleic acid in P3, P4 and P6 were lower than the control.

An increase in linolenic acid in the broiler fed diet containing Sauropus androgynus leaf in the present study agrees with the observation of Santoso et al. $(2015,2017 \mathrm{c})$ that fermented Sauropus androgynus leaf powder or fermented Sauropus androgynus leaf extract increased linolenic acid of broiler meats. The present study disagrees with Kurniawan et al. (2015) who reported that the inclusion of noni fruit did not increase linonelic acid of duck meat. The improvement of linolenic acid of broiler meats in the present study is in contrast with the observation of Dany et al. (2016) in which 
Table 3. The Effect of Medicinal Herb on Amino Acid Composition of Female Broiler Meats

\begin{tabular}{lcccccccc}
\hline Variables, $\%$ & $\mathrm{P} 0$ & $\mathrm{P} 1$ & $\mathrm{P} 2$ & $\mathrm{P} 3$ & $\mathrm{P} 4$ & $\mathrm{P} 5$ & $\mathrm{P} 6$ & $\begin{array}{c}\mathrm{P}- \\
\text { values }\end{array}$ \\
\hline Aspartic acid & $1.71 \pm 0.11$ & $1.71 \pm 0.38$ & $1.63 \pm 0.09$ & $1.81 \pm 0.15$ & $1.68 \pm 0.07$ & $1.60 \pm 0.07$ & $1.58 \pm 0.26^{\mathrm{ns}}$ & 0.366 \\
Glutamic acid $3.87 \pm 0.07^{\mathrm{c}}$ & $3.04 \pm 0.43^{\mathrm{b}}$ & $2.75 \pm 0.20^{\mathrm{ab}}$ & $2.98 \pm 0.41^{\mathrm{b}}$ & $2.52 \pm 0.81^{\mathrm{a}}$ & $2.50 \pm 0.33^{\mathrm{a}}$ & $2.36 \pm 0.43^{\mathrm{a}^{* *}}$ & 0.0006 \\
Serine & $0.41 \pm 0.18$ & $0.64 \pm 0.13$ & $0.62 \pm 0.08$ & $0.63 \pm 0.12$ & $0.62 \pm 0.07$ & $0.57 \pm 0.08$ & $0.51 \pm 0.09^{\mathrm{ns}}$ & 0.074 \\
Histidine & $0.44 \pm 0.04$ & $0.50 \pm 0.05$ & $0.46 \pm 0.03$ & $0.49 \pm 0.06$ & $0.47 \pm 0.03$ & $0.39 \pm 0.06$ & $0.42 \pm 0.12^{\mathrm{ns}}$ & 0.735 \\
Glycine & $0.53 \pm 0.15$ & $0.87 \pm 0.07$ & $0.84 \pm 0.07$ & $0.88 \pm 0.46$ & $0.77 \pm 0.12$ & $0.64 \pm 0.21$ & $0.68 \pm 0.08^{\mathrm{ns}}$ & 0.187 \\
Threonine & $0.60 \pm 0.15$ & $0.74 \pm 0.14$ & $0.70 \pm 0.04$ & $0.65 \pm 0.24$ & $0.65 \pm 0.21$ & $0.62 \pm 0.14$ & $0.60 \pm 0.14^{\mathrm{ns}}$ & 0.834 \\
Arginine & $1.11 \pm 0.11$ & $1.21 \pm 0.14$ & $1.14 \pm 0.06$ & $1.05 \pm 0.39$ & $1.19 \pm 0.10$ & $1.02 \pm 0.20$ & $1.00 \pm 0.20^{\mathrm{ns}}$ & 0.644 \\
Alanine & $1.24 \pm 0.16^{\mathrm{b}}$ & $1.09 \pm 6.13^{\mathrm{b}}$ & $1.08 \pm 0.02^{\mathrm{b}}$ & $1.07 \pm 0.07^{\mathrm{b}}$ & $1.08 \pm 0.06^{\mathrm{b}}$ & $0.89 \pm 17^{\mathrm{a}}$ & $0.83 \pm 0.22^{\mathrm{a}^{* *}}$ & 0.007 \\
Tyrosine & $0.54 \pm 0.08$ & $0.63 \pm 0.08$ & $0.52 \pm 0.09$ & $0.59 \pm 0.14$ & $0.71 \pm 0.23$ & $0.51 \pm 0.06$ & $0.51 \pm 0.09^{\mathrm{ns}}$ & 0.240 \\
Methionine & $0.39 \pm 0.07^{\mathrm{a}}$ & $0.55 \pm 0.06^{\mathrm{b}}$ & $0.41 \pm 0.11^{\mathrm{a}}$ & $0.54 \pm 0.09^{\mathrm{b}}$ & $0.52 \pm 0.02^{\mathrm{b}}$ & $0.43 \pm 0.06^{\mathrm{ab}}$ & $0.51 \pm 0.11^{\mathrm{b}^{*}}$ & 0.027 \\
Valine & $0.95 \pm 0.0 .03$ & $0.92 \pm 0.13$ & $0.88 \pm 0.09$ & $1.03 \pm 0.10$ & $0.92 \pm 0.08$ & $0.81 \pm 0.13$ & $0.77 \pm 0.15^{\mathrm{ns}}$ & 0.084 \\
Phenylalanine & $0.63 \pm 0.23$ & $0.78 \pm 0.11$ & $0.72 \pm 0.04$ & $0.83 \pm 0.05$ & $0.70 \pm 0.07$ & $0.68 \pm 0.08$ & $0.62 \pm 0.11^{\mathrm{ns}}$ & 0.478 \\
I-leucine & $0.90 \pm 0.10$ & $0.95 \pm 0.11$ & $0.80 \pm 0.19$ & $1.05 \pm 0.09$ & $0.91 \pm 0.11$ & $0.82 \pm 0.14$ & $0.83 \pm 0.12^{\mathrm{ns}}$ & 0.451 \\
Leucine & $1.38 \pm 0.11$ & $1.47 \pm 0.21$ & $1.42 \pm 0.04$ & $1.22 \pm 0.29$ & $1.56 \pm 0.20$ & $1.30 \pm 0.15$ & $1.26 \pm 0.21^{\mathrm{ns}}$ & 0.172 \\
Lysine & $1.33 \pm 0.24$ & $1.67 \pm 0.34$ & $1.41 \pm 0.15$ & $1.52 \pm 0.25$ & $1.63 \pm 0.25$ & $1.53 \pm 0.27$ & $1.36 \pm 0.25^{\mathrm{ns}}$ & 0.419 \\
Amino acid & $14.68 \pm 0.62$ & $15.08 \pm 1.90$ & $13.95 \pm 0.87$ & $14.79 \pm 1.60$ & $14.27 \pm 1.14$ & $12.77 \pm 1.63$ & $12.47 \pm 1.96^{\mathrm{ns}}$ & 0.176 \\
\hline & & & & & & & & \\
\hline
\end{tabular}

$\mathrm{P} 0=$ the control; $\mathrm{P} 1=$ Sauropus androgynus leaf; $\mathrm{P} 2=$ Bay leaf; $\mathrm{P} 3=$ Basil leaf; $\mathrm{P} 4=$ Papaya leaf; $\mathrm{P} 5=$ Moring $a$ leaf; $\mathrm{P} 6=$ Noni fruit.

Moringa leaf meal inclusion reduced linolenic acid in the intramuscular fat of the Longissimus dorsi muscle of pig. The present results showed similar results to the observation of Kirubakaran et al. (2011) that the inclusion of basil leaf meal at 1 and $2 \mathrm{~g} / \mathrm{kg}$ contributed significantly to elevating the yolk linolenic acid. Jafari et al. (2017) reported that the inclusion of papaya leaf extract increased linolenic acid of the rumen liquor.

Reduction of meat oleic acid in broiler chickens fed diet containing either noni fruit or papaya leaf in the present study is in contrast with Kurniawan et al. (2015) who reported that the inclusion of noni fruit at 3\% did not reduce oleic acid of duck meats, and Jafari et al. (2017) who reported that papaya leaf inclusion did not reduce oleic acid of rumen liquor. The present study, however, agrees with the observation of Kirubakaran et al. (2011) who reported that basil leaf inclusion reduced oleic acid of layer yolk.

This research might help to maintain broiler chickens without the need for antibiotics as a feed additive and to develop organic farming for broiler chickens.In addition, the present study might help to develop enriched meats (these meats contained lower fat but higher in protein, mineral, methionine, linolenic acid with no antibiotic residue), which will meet the demand of consumers.

\section{CONCLUSION}

The inclusion of medicinal herbs did not reduce fat deposition in female broiler chickens. The selected medicinal herbs increased linolenic and omega 3 unsaturated fatty acids and kalium of broiler meats but reduced glutamic acid of broiler meats. Female broiler chickens fed diet containing either Sauropus androgynus or papaya leaves had lower meat fat as compared with the control. Furthermore, female broiler chickens fed diet containing Sauropus androgynus leaf increased 
Table 4. The Effect of Medicinal Herb on Fatty Acid Composition of Female Broiler Meats

\begin{tabular}{|c|c|c|c|c|c|c|c|c|}
\hline Variables, $\%$ fat & P0 & P1 & $\mathrm{P} 2$ & P3 & $\mathrm{P} 4$ & P5 & P6 & $\begin{array}{c}\text { P- } \\
\text { values }\end{array}$ \\
\hline $\begin{array}{l}\text { Lauric acid, } \\
\text { C12:0 }\end{array}$ & $0.04 \pm 0.02$ & $94 \pm 0.01$ & $04 \pm 0.01$ & $0.03 \pm 0.00$ & $03 \pm 0.01$ & $0.03 \pm 0.01$ & $0.03 \pm 0.00^{\mathrm{ns}}$ & 0.620 \\
\hline $\begin{array}{l}\text { Myristic acid, } \\
\text { C14:0 }\end{array}$ & $0.44 \pm 0.02$ & $0.48 \pm 0.02$ & $0.45 \pm 0.06$ & $0.44 \pm 0.05$ & $0.50 \pm 0.03$ & $0.47 \pm 0.02$ & $0.48 \pm 0.02^{\mathrm{ns}}$ & 0.836 \\
\hline $\begin{array}{l}\text { Myristeloic acid, } \\
\text { C14:1 }\end{array}$ & $0.13 \pm 0.02$ & $0.13 \pm 0.01$ & $0.12 \pm 0.03$ & $0.13 \pm 0.02$ & $0.14 \pm 0.03$ & $0.13 \pm 0.01$ & $0.13 \pm 0.01^{\mathrm{ns}}$ & 0.158 \\
\hline $\begin{array}{l}\text { Penthadecanoic acid, } \\
\text { C15:0 }\end{array}$ & $0.06+0.01$ & $0.07 \pm 0.01$ & $0.06 \pm 0.01$ & $0.06 \pm 0.01$ & $0.06 \pm 0.01$ & $0.06 \pm 0.01$ & $0.07 \pm 0.01^{\mathrm{ns}}$ & 0.839 \\
\hline $\begin{array}{l}\text { Palmitic acid, } \\
\text { C16:0 }\end{array}$ & $19.90 \pm 0.25$ & $18.73 \pm 0.67$ & $19.04 \pm 0.85$ & $18.74 \pm 1.08$ & $18.96 \pm 1.00$ & $19.52 \pm 0.56$ & $19.61 \pm 0.62^{\mathrm{ns}}$ & 0.414 \\
\hline $\begin{array}{l}\text { Palmitoleic acid, } \\
\text { C16:1 }\end{array}$ & $4.64 \pm 0.70$ & $4.48 \pm 0.18$ & $4.26 \pm 0.77$ & $4.80 \pm 0.66$ & $4.61 \pm 0.80$ & $4.77 \pm 0.43$ & $4.50 \pm 0.51^{\mathrm{ns}}$ & 0.891 \\
\hline $\begin{array}{l}\text { Heptadecanoic acid, } \\
\text { C17:0 }\end{array}$ & $0.08 \pm 0.02$ & $0.10 \pm 0.01$ & $0.09 \pm 0.02$ & $0.09 \pm 0.01$ & $0.10 \pm 0.01$ & $0.10 \pm 0.01$ & $0.10 \pm 0.01^{\mathrm{ns}}$ & 0.645 \\
\hline $\begin{array}{l}\text { Cis-10-heptadeca- } \\
\text { noic acid, C17:1 }\end{array}$ & $0.07 \pm 0.01$ & $0.08 \pm 0.01$ & $0.07 \pm 0.01$ & $0.08 \pm 0.01$ & $0.08 \pm 0.01$ & $0.07 \pm 0.01$ & $0.07 \pm 0.01^{\mathrm{ns}}$ & 0.633 \\
\hline $\begin{array}{l}\text { Stearic acid, } \\
\text { C18:0 }\end{array}$ & $3.68 \pm 0.35$ & $3.65 \pm 0.18$ & $3.86 \pm 0.17$ & $3.57 \pm 0.28$ & $3.78 \pm 0.10$ & $3.80 \pm 0.14$ & $3.97 \pm 0.19^{\mathrm{ns}}$ & 0.206 \\
\hline $\begin{array}{l}\text { Elaidic acid, } \\
\text { C18:1n9t }\end{array}$ & $0.23 \pm 0.02$ & $0.33 \pm 0.30$ & $0.23 \pm 0.05$ & $0.22 \pm 0.04$ & $0.19 \pm 0.05$ & $0.22 \pm 0.03$ & $0.22 \pm 0.03^{\mathrm{ns}}$ & 0.779 \\
\hline $\begin{array}{l}\text { Oleic acid, } \\
\text { C18:1n9c }\end{array}$ & $37.15 \pm 1.66^{\mathrm{b}}$ & $35.91 \pm 0.93^{\mathrm{ab}}$ & & $34.15 \pm 1.27^{\mathrm{a}}$ & $34.37 \pm 1.47^{\mathrm{a}}$ & $36.01 \pm 1.40^{\mathrm{b}}$ & $35.06 \pm$ & 0.030 \\
\hline $\begin{array}{l}\text { Linoleic acid, } \\
\text { C18:2n6c }\end{array}$ & $11.74 \pm 1.09$ & $14.20 \pm 2.43$ & $13.73 \pm 1.23$ & $12.70 \pm 0.90$ & $14.22 \pm 2.10$ & $13.28 \pm 0.40$ & $14.31 \pm 1.48^{\mathrm{ns}}$ & 0.202 \\
\hline $\begin{array}{l}\text { Arachidic acid, } \\
\text { C20:0 }\end{array}$ & $0.05 \pm 0.01$ & $0.06 \pm 0.01$ & $0.05 \pm 0.01$ & $0.05 \pm 0.01$ & $0.06 \pm 0.01$ & $0.05 \pm 0.01$ & $0.06 \pm 0.01^{\mathrm{ns}}$ & 0.117 \\
\hline $\begin{array}{l}\gamma \text {-linoleic acid, } \\
\text { C18:3n6 }\end{array}$ & $0.12 \pm 0.01$ & $0.13 \pm 0.03$ & $0.13 \pm 0.01$ & $0.12 \pm 0.02$ & $0.15 \pm 0.03$ & $0.12 \pm 0.01$ & $0.14 \pm 0.04^{\mathrm{ns}}$ & 0.451 \\
\hline $\begin{array}{l}\text { Cis-11-eicoseneic } \\
\text { acid, C20:1 }\end{array}$ & $0.18 \pm 0.05$ & $0.18 \pm 0.03$ & $0.16 \pm 0.02$ & $0.16 \pm 0.02$ & $0.16 \pm 0.03$ & $0.19 \pm 0.0 .01$ & $0.16 \pm 0.01^{\mathrm{ns}}$ & 0.493 \\
\hline $\begin{array}{l}\text { Linolenic acid, } \\
\text { C18:3n3 }\end{array}$ & $0.36 \pm 0.06^{\mathrm{a}}$ & $0.64 \pm 0.08^{b}$ & $0.55 \pm 0.08^{\mathrm{b}}$ & $0.55 \pm 0.09^{\mathrm{b}}$ & $0.58 \pm 0.11^{\mathrm{b}}$ & $0.52 \pm 0.05^{\mathrm{b}}$ & $0.53 \pm 0.05^{\mathrm{b}^{* *}}$ & 0.002 \\
\hline $\begin{array}{l}\text { Cis-11,14-icose- } \\
\text { dienoic acid, C20:2 }\end{array}$ & $0.11 \pm 0.03$ & $0.12 \pm 0.02$ & $0.12 \pm 0.01$ & $0.11 \pm 0.02$ & $0.12 \pm 0.01$ & $0.12 \pm 0.01$ & $0.12 \pm 0.01^{\mathrm{ns}}$ & 0.905 \\
\hline $\begin{array}{l}\text { Behenic acid, } \\
\text { C22:0 }\end{array}$ & $0.03 \pm 0.01$ & $0.04 \pm 0.01$ & $0.03 \pm 0.01$ & $0.03 \pm 0.01$ & $0.04 \pm 0.01$ & $0.03 \pm 0.01$ & $0.03 \pm 0.01^{\mathrm{na}}$ & 0.317 \\
\hline $\begin{array}{l}\text { Cis-8,11,14-eicose- } \\
\text { trienoicacid,C20:3n6 }\end{array}$ & $0.13 \pm 0.01$ & $0.16 \pm 0.02$ & $0.16 \pm 0.01$ & $0.14 \pm 0.02$ & $0.17 \pm 0.02$ & $0.17 \pm 0.02$ & $0.15 \pm 0.03^{\mathrm{ns}}$ & 0.093 \\
\hline $\begin{array}{l}\text { Arachidonic acid, } \\
\text { C20:4n } 6\end{array}$ & $0.39+0.08$ & $0.54 \pm 0.17$ & $0.56 \pm 0.10$ & $0.48 \pm 0.22$ & $0.61 \pm 0.10$ & $0.53 \pm 0.07$ & $0.52 \pm 0.08^{\mathrm{ns}}$ & 0.369 \\
\hline $\begin{array}{l}\text { Lignoceric acid, } \\
\text { C24:0 }\end{array}$ & $0.02 \pm 0.02^{b}$ & $0.02 \pm 0.02^{b}$ & $0.04 \pm 0.02^{\mathrm{c}}$ & $0.02 \pm 0.01^{\mathrm{b}}$ & $0.02 \pm 0.01^{\mathrm{a}}$ & $0.01 \pm 0.01^{\mathrm{a}}$ & $0.01 \pm 0.01^{\mathrm{a}^{*}}$ & 0.012 \\
\hline $\begin{array}{l}\text { Cis-5,811,14,17- } \\
\text { eicosapentaenoic } \\
\text { acid, C20:5n3 }\end{array}$ & $0.03 \pm 0.01$ & $0.04 \pm 0.01$ & $0.04 \pm 0.02$ & $0.04 \pm 0.01$ & $0.03 \pm 0.01$ & $0.04 \pm 0.01$ & $0.04 \pm 0.02^{\mathrm{ns}}$ & 0.771 \\
\hline
\end{tabular}


Table 4. The Effect of Medicinal Herb on Fatty Acid Composition of Female Broiler Meats (continues)

\begin{tabular}{|c|c|c|c|c|c|c|c|c|}
\hline Variables, $\%$ fat & P0 & P1 & $\mathrm{P} 2$ & $\mathrm{P} 3$ & P4 & P5 & P6 & $\begin{array}{c}\text { P- } \\
\text { values }\end{array}$ \\
\hline $\begin{array}{l}\text { Cis-4,7,10,13,16,19- } \\
\text { docosahexaenoic acid, } \\
\text { C22:6n3 }\end{array}$ & $0.05 \pm 0.01$ & $0.06 \pm 0.03$ & $0.04 \pm 0.02$ & $0.07 \pm 0.05$ & $0.05 \pm 0.03$ & $0.05 \pm 0.02$ & $0.05 \pm 0.02$ & 0.853 \\
\hline Total fatty acids & $79.60 \pm 1.08$ & $80.15 \pm 3.26$ & $80.80 \pm 1.90$ & $76.72 \pm 1.90$ & $79.02 \pm 2.83$ & $80.26 \pm 2.17$ & $80.33 \pm 03.73^{\mathrm{ns}}$ & 0.365 \\
\hline Saturated fatty acids & $24.19 \pm 1.41$ & $23.06 \pm 0.64$ & $23.53 \pm 0.74$ & $22.92 \pm 1.24$ & $23.43 \pm 1.03$ & $23.98 \pm 0.67$ & $24.25 \pm 0.50^{\mathrm{ns}}$ & 0.333 \\
\hline Unsaturated fatty acid & $55.17 \pm 1.19$ & $56.84 \pm 3.55$ & $57.01 \pm 1.31$ & $53.56 \pm 1.31$ & $55.33 \pm 2.91$ & $56.04 \pm 1.55$ & $55.85 \pm 3.54^{\mathrm{ns}}$ & 0.494 \\
\hline - Omega 3 & $0.44 \pm 0.07^{\mathrm{a}}$ & $0.74 \pm 0.11^{\mathrm{b}}$ & $0.63 \pm 0.08^{b}$ & $0.63 \pm 0.14^{\mathrm{b}}$ & $0.67 \pm 0.11^{\mathrm{b}} 0$ & $0.61 \pm 0.04^{b}$ & $0.63 \pm 0.05^{\mathrm{b}^{*}}$ & 0.010 \\
\hline - Omega 6 & $12.30 \pm 1.14$ & $14.93 \pm 2.59$ & $14.46 \pm 1.30$ & $13.35 \pm 1.13$ & $15.03 \pm 2.20$ & $13.98 \pm 0.45$ & $15.02 \pm 1.58^{\mathrm{ns}}$ & 0.198 \\
\hline - Omega 39 & $37.38 \pm 1.66^{\mathrm{b}}$ & $36.24 \pm 1.07^{\mathrm{b}}$ & $37.23 \pm 0.72^{\mathrm{b}}$ & $34.36 \pm 1.30^{\mathrm{a}}$ & $34.57 \pm 1.46^{\mathrm{a}}$ & $36.22 \pm 17^{b}$ & $35.27 \pm 1.86^{\mathrm{a}^{*}}$ & 0.030 \\
\hline
\end{tabular}

$\mathrm{P} 0=$ the control; $\mathrm{P} 1=$ Sauropus androgynus leaf; $\mathrm{P} 2=$ Bay leaf; $\mathrm{P} 3=$ Basil leaf; $\mathrm{P} 4=$ Papaya leaf; $\mathrm{P} 5=$ Moringa leaf; $\mathrm{P} 6=$ Noni fruit

meat iron. Broiler fed diet containing either Sauropus androgynus leaf, bay bay leaf, papaya leaf or noni fruit increased meat calcium. Broiler fed diet containing either Sauroupus androgynus leaf, papaya leaf, Moringa leaf or noni fruit increased meat phosphorus. It was concluded that Sauropus androgynus leaf was the most effective to produce broiler meats, which low in fat content but high in protein, mineral and omega 3 unsaturated fatty acids.

\section{ACKNOWLEDGEMENTS}

The authors thanks to the Directorat General of Higher Education, Ministry of Researh, Technology and Higher Education, Indonesia under contrant number 890/UN30.15/LT/2017.

\section{REFERENCES}

Abdalla, H. O., N. N. A. Ali, F. S. Siddig and S. A. M. Ali. 2013. Improving tenderness of spent layer hens meat using papaya leaves (Carica papaya). Pak. Vet. J. 33(1):73-76.

Aiura, F.S. and M.R.B. de Carvalho, 2007. Body lipid deposition in Nile tilapia fed on rations containing tannin. Pesq. Agropec. Bras. 42(1): 51-56.

Al Juhaimi, F., E. E. Babiker, K. Ghafoor and M. M. Ozcan. 2016. Fatty acid composition of three different Moringa leave oils. La Rivista Delle Sostanze Grasse, Vol. XCIII:111-113.
Alla, G., Al-Hashimi and S. A. Mahmood. 2016. The nutritional value and antioxidant activity of bay leaves (Laurusn obilis L.). Bas. J. Vet. Res. 15(4):10-23.

Al-Fataftah, A. A., S. M. Herzallah, K. Alshawabkeh and S. A. Ibrahim. 2013. Administration of lactic acid bacteria to enhance synthesis of vitamin B12 and B6 and lower cholesterol levels in poultry meat. J. Food Agric. Environ. 11(2):604-609.

Almeida, J. C. de, M. S. Perassolo, J. L. Camargo, N. Bragagnolo and J. L. Gross, 2006. Fatty acid composition and cholesterol content of beef and chicken meat in Southern Brazil. Bra. J. Pharmaceutical Sci. 42(1):109-117.

Anavi, S. 2013. Nutrition and Health- The Importance of Potassium. International Potash Institute. Editor P. Imas. ISBN 9783-905887-08-2.

AOAC, 2012. Official Methods of analysis. 19 ed. Association of Official Analytical Chemist, Washington, D. C.

Atowadi, S. E., J. C. Atowadi, G. A. Idakwo, B. Pfundstein, R. Haubner, G. Wurtele, H. Bartsch and R. W. Owen. 2010. Evaluation of the polyphenol content and antioxidant properties of methanol extracts of the leaves, stem, and root barks of Moringa oleifera Lam. J. Med. Food 13:710-716.

Basar, S. and J. Westendorf. 2012. Mineral and trace element concentrations in Morinda citrifolia L. (noni) leaf, fruit and fruit juice. Food Nutr. Sci. 3: 1176-1188. 
Barton, M. D. and W. S. Hart. 2001. Public health risks: Antibiotic resistance- A review. AsianAust. J. Anim. Sci. 14:414-422.

Bleiziffer, R., C. Mesaros, S. Sulvar, P. Podea, A. Iordache, F. D. Yudin and M. Culea. 2017. Comparative characterization of basil, mint and sage extracts. Studia Ubb Chemia, LXII, 2, Tom II, 2017 (p. 373-385).

Dany, D. C., O. O. Jorge, S. V. Ángel, S. D. Enrique, P. R. Valentín, M. H. Víctor and S.F. Luis. 2016. Effect of Moringa olifera meal inclusion on meat quality from the Mexican Hairless Pig. ARPN J. Agric. Biol. Sci. 11(4):131-141.

Dinh, T. T. N., J. R. Blanton Jr., J. C. Brooks, M. F. Miller and L. D. Thompson. 2008. A simplified method for cholesterol determination in meat and meat products. J. Food Composition Analysis. 21(4):306-314.

Dinh, T. T. N., L. D. Thompson, M. L. Galyean, J. C. Brooks, K. Y. Patterson and L. M. Boylan. 2011. Cholesterol content and methods for cholesterol determination in meat and poultry. Comprehensive Reviews in Food Sci. Food Safety. 10(5):269-289.

Dzida, K. 2010. Nutrients contents in sweet basil (Ocimum basilicum L.) herb depending on calcium carbonate dose and cultivar. Acta Sci. Por., Hortorum Cultus, 9: 143-151.

Fenita, Y., Warnoto and A. Nopis. 2011. Pengaruh pemberian air buah mengkudu (Morinda citrifolia L.) terhadap kualitas karkas ayam broiler. J. Sain Peternakan Indonesia 6:143150.

Gopalakrishnan, N., K. Doriya and D.S. Kumar. 2016. Moringa oleifera: A review on nutritive importance and its medicinal application. Food Sci. Human Wellness. 5: 49-59.

Gurbuz, Y. and I. A. Ismael. 2016. Effect of peppermint and basil as feed additive on broiler performance and carcass characteristics. Iranian J. App. Anim. Sci. 6:149-156.

Hamiyanti, A. A., B. Sutomo, A. F. Rozi, Y. Adnyono and R. Darajat. 2013. Pengaruh penambahan tepung kemangi (Ocimum basilicum) terhadap komposisi kimia dan kualitas fisik ayam broiler. Jurnal Ilmu-Ilmu Peternakan 23 (1):25-29.

Henderson, J. W. Jr. and A. Brooks. 2010. Improved amino acid methods using agilent zorbax eslipse plus C18 columns for a variety of agilent $\mathrm{LC}$ instrumentation and separation goals.Agilent Technologies, Inc. 2850 Centerville Rd Wilmington, DE 19808, USA.

Hoe, V. B. and K. H. Siong. 1999. The nutritional value of indigenous fruits and vegetables in Sarawak. Asia Pac. J. Clin. Nutr. 8(1):24-31.

Imik, H., A. Hayirli, L. Turgut, E. Lacin, S. Celebi, F. Koc and L. Yildiz. 2006. Effects of additive on laying performance, metaboloic profile, and egg quality of hens fed a high level sorghum (Sorghum vulgare) during the peak layaing period. Asian-Aust. J. Anim. Sci. 19:573-581.

Ismoyowati, D. Indrasanti and J. Sumarmono. 2016. Blood biochemical profiles, growth performance, carcass characteristics and meat quality of Mallard and Muscovy ducks fed diet supplemented with bay leaf (Syzygium polyanthum). Int. J. Poultry Sci. 15:21-26.

Jafari, S., Y. M. Goh, M. A. Rajion, M. F. Jahromi, Y. H. Ahmad and M. Ebrahim. 2017 Papaya (Carica papaya) leaf methanolic extract modulates in vitro rumen methanogenesis and rumen biohydrogenation. Anim. Sci. J. 88:267-276.

Khaksefidi, A and Sh. Rahimi. 2005. Effect of probiotic inclusion in the diet of broiler chickens on performance, feed efficiency and carcass quality. Asian-Aust. J. Anim. Sci. 18:1153-1156.

Kirubakaran, A., D. Narahari, T. E. Valavan and A. S. Kumar. 2011. Effects of flaxseed, sardines, pearl millet, and holy basil leaves on production traits of layers and fatty acid composition of egg yolks. Poultry Sci. 90:147-156.

Kurniawan, D, E. Widodo and I. H. Djunaidi. 2015. Lipid profiles of blood serum and fatty acid composition of meat of hybrid duck fed diet supplemented with noni (Morinda citrifolia) fruit meal. JITV 20(3):200-206.

Lee, O. H., H. B.Lee, J. Lee, J.Y. Son, S. K. Rhee, H. D. Kim, Y. C. Kim and B. Y. Lee.2005. Chemical properties of olive and bay leaves. J. Korean Soc. Food Sci. Nutr. 34(4):503508.

Lindsay, C. and K. D. Golden. 2012. Morinda citrifolia: Amino acid and lipid content of the noni fruit at various stages of maturity. J. Sci. Res. 4(2):467-476.

Liu, B., W. Li, Y. Chang, W. Dong and L. Ni. 2006. Extraction of berberine from rhizome 
of Coptis chinensis Franch using supercritical fluid extraction. J. Pharm. Biomed. Anal. 41:1056-1060.

Moyo, B., S. Oyedemi, P. J. Masika and V. Muchenje. 2012. Polyphenolic content and antioxidant properties of Moringa oleifera leaf extracts and enzymatic activity of liver from goats supplemented with Moringa oleifera leaves/sunflower seed cake. Meat Sci. 91:441-447.

Okereke, C. J. and J. O. Akaninwor. 2013. The protein quality of raw leaf, seed and root of Moringa oleifera grown in Rivers State, Nigeria. Annals Biol. Res., 4 (11):34-38.

Olaofe, O., E. I. Adeyeye and S. Ojugbo. 2013. Comparative study of proximate, amino acids and fatty acids of Moringa oleifera tree. Elixir Appl. Chem. 54:12543-12554.

Renkema, K. Y., R. T. Alexander, R. J. Bindels and J. G. Hoederop. 2008. Calcium and phosphate homeostasis: Concerted interplay of new regulators. Annals Med. 40:82-91.

Restiayanti, L., I. G. N. G. Bidura and N. L. G. Sumardani. 2014. Pengaruh pemberian ekstrak daun kelor (Moringa oleifera Lam) dan daun bawang putih (Allium sativum) melalui air minum terhadap distribusi lemak tubuh dan kadar kolesterol broiler umur 2-6 minggu. Peternakan Tropika, 2(3):402-414.

Santoso, U., S. Ohtani and K. Tanaka. 2000. Tuchung leaf meal supplementation reduced an increase in lipid accumulation of chickens stimulated by dietary cholesterol. Asian-Aus. J. Anim. Sci. 13:1758-1763.

Santoso, U. 2001. Pengaruh ekstrak daun katuk terhadap mutu karkas ayam broiler. Buletin Ilmu Peternakan dan Perikanan. 7: 22-28.

Santoso, U. and Sartini. 2001. Reduction of fat accumulation in broiler chickens by Sauropus androgynus (Katuk) leaf meal supplementation. Asian-Aust. J. Anim. Sci. 14:346-350.

Santoso, U., Suharyanto and E. Handayani. 2001. Effects of Sauropus androgynus (katuk) leaf extract on growth, fat accumulation and fecal microorganisms in broiler chickens. J. Ilmu Ternak Vet. 6(4):220-226.

Santoso, U., J. Setianto and T. Suteky. 2005. Effect of Sauropus androgynus (katuk) extract on egg production and lipid metabolism in layers. Asian-Aust. J. Anim. Sci. 18:364-369.

Santoso, U., Kususiyah, Y. Fenita, S. Winarsih and A. M. H. Putranto. 2010. Pengaruh suplementasi ekstrak daun katuk plus tepung kunyit pada pakan broiler berlemak tinggi terhadap kualitas karkas dan berat organ dalam. J. Sain Peternakan Indonesia 5:8794.

Santoso, U. 2014. Katuk, Tumbuhan Obat Multikhasiat. Badan Penerbit Fakultas Pertanian (BPFP) Universitas Bengkulu, Bengkulu.

Santoso, U. 2015. Pengaruh ekstrak daun pepaya terhadap berat badan, toksisitas, karakteristik organoleptik dan kualitas daging pada broiler. J. Inovasi. 1(2):67-76.

Santoso, U. and Y. Fenita. 2015. Pengaruh pemberian daun pepaya (Carica papaya) terhadap kadar protein dan lemak pada telur puyuh. J. Sain Peternakan Indonesia. 10:7176.

Santoso, U., Y. Fenita, Kususiyah and I. G. N. G. Bidura. 2015. Effect of fermented Sauropus androgynus leaves on meat composition, amino acid and fatty acid compositions in broiler chickens. Pak. J. Nutr. 14:799-807.

Santoso, U and Y. Fenita. 2016. The effect of Sauropus androgynus leaf extract on performance, egg quality and chemical composition of eggs. J. Indonesian Trop. Anim. Agric. 41(3):125-134.

Santoso, U. Y. Fenita and E. Sulistyowati. 2017a. Effect of Sauropus androgynus leaf extract, fish oil and vitamin $\mathrm{E}$ on performance, egg quality and composition in laying hens. J.Indonesian Trop.Anim.Agric. 42(2):88-98.

Santoso, U., Y. Fenita and Kususiyah. 2017b. The Effect of medicinal herb inclusion on hematologic status and blood lipid profiles in broiler chickens. Int. J. Poultry Sci., 16: 415-423.

Santoso, U., Y. Fenita and Kususiyah. 2017c. Effect of fermented Sauropus androgynus leaf extract on the chemical composition of broiler meat. Pak. J. Nutr. 16:306-313

Sharma, D. K., B. Tiwari, R. Kr. Singh, S. Sahu, S. C. Mathur, R. M. Singh and G. M. Singh. 2013. Estimation of minerals in Carica papaya $\mathrm{L}$. leaf found in Northern India by using ICP. Int. J. Sci. Eng. Res. 4: 10121019.

Simitzis, P. E., S. G. Deligeorgis, J. A. Bizelis, A. Dardamani, I. Theodosiou and K. Fegeros. 2008. Effect of dietary oregano oil supplementation on lamb meat characteristics. Meat Sci. 79:217-223.

Suharti, S., A. Banowati, W. Hermana and K. G. 
Wiryawan. 2008. Komposisi dan kandungan kolesterol karkas ayam broiler diare yang diberi tepung daun salam (Syzygium polyanthum Wight) dalam ransum. Media Peternakan 31:138-145.

Sujana, E., S. Darana, D. Garnida and T. Widyastuti. 2007. Efek Pemberian Ransum Mengandung Tepung Buah Mengkudu (Morinda citrifolia Linn.) terhadap Kandungan Kolesterol, Persentase Karkas dan Lemak Abdominal Ayam Broiler Prosiding Seminar Nasional Teknologi Peternakan dan Veteriner 2007. Puslitbang Peternakan, Bogor. P. 556-561.

Suzana, D., F. D. Suyatna, Azizahwati, R. Andrajati, S. P. Sari and A. Mun'im. 2017. Effect of Moringa oleifera leaves extract against hematology and blood biochemical value of patients with iron deficiency anemia. J. Young Pharm. 9(1) Suppl:s79s84.

Tazi, S. M. A. El. 2014. Effect of feeding different levels of Moringa oleifera leaf meal on the performance and carcass quality of broiler chicks. Int. J. Sci. Res. 3:147-151.

Tessera, G. M., A. Haile and E. Kinfe. 2015. Bioavailability of minerals in cookies developed from blend of Moringa leaf powder and wheat flour for iron deficient lactating mothers. Int. J. Food Sci. Nutr. Engineering. 5(6):226-232.
Tonga, Y. N. K. Mardewi, N. K. E. Suwitari, N. K. S. Rukmini, N. M. G. R. Astiti and I. G. A. D. S. Rejeki. 2016. Suplementasi tepung daun kelor (Moringa oleifera) pada ransum untuk meningkatkan kualitas daging ayam broiler. Seminar Nasional Peternakan 2, Fakultas Peternakan, Universitas Hasanuddin, August 25, 2016. P. 45-51.

Vidhani, S. I., V. G. Vyas, H. J. Parmar, V. M. Bhalani, M. M. Hassan, A. Gaber, B. A. Golakiya. 2016. Evaluation of some chemical composition, minerals, fatty acid profiles, antioxidant and antimicrobial activities of Tulsi (Ocimum sanctum) from India. Am. J. Food Sci. Technol. 4:52-57.

Zang, M., S. Xu, K.A. Maitland-Toolan, A. Zuccollo, X. Hou, B. Jiang, M. Wierzbicki, T.J. Verbeuren and R.A.Cohen, 2006. Polyphenols stimulate AMP-activated protein kinase, lower lipids and inhibit accelerated atherosclerosis in diabetic LDL receptor-deficient mice. Diabetes. 55:21802191.

Zarrouki, B., N.J. Pillon, E. Kalbacher, H.A. Soula, G. Nia N'Jomen, L. Grand, S. Chambert, A. Geloen and C.O. Soulage, 2010. Cirsimarin, a potent antilipogenic flavonoid, decreases fat deposition in mice intra-abdominal adipose tissue. Int. J. Obes. (Lond.). 34:1566-1575. 